\title{
Phase response curve analysis of network properties in the deep cerebellar nuclei
}

\author{
Marylka Uusisaari", Benjamin Torben-Nielsen, Klaus M Stiefel \\ From Nineteenth Annual Computational Neuroscience Meeting: CNS*2010 \\ San Antonio, TX, USA. 24-30 July 2010
}

The deep cerebellar nuclei (DCN) are the final unit of cerebellar computation, where the excitatory input into the cerebellum is integrated with inhibitory input from the cerebellar Purkinje cells. In some sense the entire state of cerebellar function can be thought of as compressed into the state of DCN network. However, even though the main cell types in DCN have recently been described [1], next to nothing is known about their roles in the DCN network, or even about the functional properties of the DCN network. This is mainly due to the difficulty of conducting in vitro experiments with this structure and the sparseness of intra-DCNconnections compared with the cortico-nuclear connections [2].

Phase response curves (PRCs) of regularly firing neurons quantify the shift in spike timing in response to perturbations [3]. The PRC is a strong theoretical tool allowing deduction of the behavior of a single neuron within a network [4]. Notably, the PRC can give insights to the emergent behavior of the neuron without detailed information about the ion channel composition. Here we propose a new bottom-up approach in forming hypotheses about the network properties in DCN, based on examining the phase response curves of individual neuronal types by 1 ) investigating the role of PRCs in discriminating different DCN cell types 2) formulating a hypothesis about the roles of these cells within the network, as different PRCs suggest involvement in different functional circuits. Since DCN neurons are spontaneously regularly firing, knowledge of the PRCs could allow significant conclusions about the in-vivo network behavior of the DCN.

We show that the large glutamatergic projection neurons of DCN exhibit type II PRCs and the local

\footnotetext{
* Correspondence: marylka.uusisaari@oist.jp

Theoretical and Experimental Neurobiology Unit, OIST, Onna-son, Okinawa, 904-0412, Japan
}

GABAergic neurons are characterized by type I PRC. In addtion, we present a single-compartmental model of DCN neuron dynamics.

\section{Published: 20 July 2010}

\section{References}

1. Uusisaari M, Obata K, Knöpfel T: Morphological and electrophysiological properties of GABAergic and non-GABAergic cells in the deep cerebellar nuclei. J Neurophysiol 2007, 97:901-11.

2. Uusisaari M, Knöpfel T: GABAergic synaptic communication in the GABAergic and non-GABAergic cells in the deep cerebellar nuclei. Neuroscience 2008, 156:537-549.

3. Gutkin BS, Ermentrout GB, Reyes AD: Phase-Response Curves Give the Responses of Neurons to Transient Inputs. J Neurophysio/ 2005, 94:1623-1635.

4. Netoff TI, Banks MI, Dorval AD, Acker CD, Haas JS, Kopell N, White JA: Synchronization in Hybrid Neuronal Networks of the Hippocampal Formation. J Neurophysiol 2005, 93:1197-1208.

\section{doi:10.1186/1471-2202-11-S1-P49}

Cite this article as: Uusisaari et al:: Phase response curve analysis of network properties in the deep cerebellar nuclei. BMC Neuroscience 2010 11(Suppl 1):P49.

\section{Submit your next manuscript to BioMed Central and take full advantage of: \\ - Convenient online submission \\ - Thorough peer review \\ - No space constraints or color figure charges \\ - Immediate publication on acceptance \\ - Inclusion in PubMed, CAS, Scopus and Google Scholar \\ - Research which is freely available for redistribution

